\title{
IN MEMORIAM \\ ACAD. PROF. DR. MOMIR POLENAKOVIC
}

\section{Doncho Donev}

Institute of Social Medicine, Faculty of Medicine, Ss. Cyril and Methodius University, Skopje, N Macedonia

Corresponding author: Doncho Donev, MD, PhD, Professor, Institute of Social Medicine, Faculty of Medicine, Ss. Cyril and Methodius University, 1000 Skopje, R.N. Macedonia. Phone: +389 70 244760, e-mail:dmdonev@ gmail.com

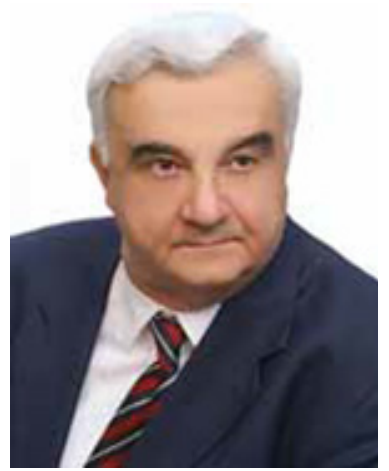

On March 6, 2021, Academician Prof. Dr. Momir Haralampie Polenakovic passed away. Acad. Prof. Dr. Momir Polenakovic was a leader of clinical and preventive nephrology in Macedonia and beyond. He was born on April $26^{\text {th }}, 1939$, in Skopje. In 1963 he graduated from the Faculty of Medicine (FM) in Skopje as the best student of his class, holding an average grade of 9.68 out of 10. In 1964 he was employed at the Institute of Pharmacology and in 1965 at the Clinic for Internal Diseases at the FM-Skopje. He completed his specialization in internal medicine in 1969 and was hired as an assistant lecturer. In 1975 he was employed at the Nephrology Clinic as the head of the Department for etiostructural assessment of renal diseases.

In 1977 he defended his doctoral dissertation at the FM-Skopje on the topic of "Clinical-immunological assessment of pathological events in the renal glomeruli". In 1977 he was hired on as an Assistant Professor, then promot- ed to Assoc. Professor in 1983 and finally was made a Full Professor in 1988. In 1997 he was elected as a member of the Macedonian Academy of Sciences and Arts (MASA).

He improved his expertise in the field of nephrology at a number of well-known centres in SFR Yugoslavia and abroad. In 1971 he started his subspecialisation in the field of nephroimmunopathology with two-month stays at the Institute for Biological Research in Belgrade, the Clinic for Nephrology at the Military Medical Academy, and the Institute for Kidney Diseases and Metabolic Disorders at the Clinical Hospital in Belgrade. In the academic year of 1972/73 he continued his research at Northwestern University in Chicago, USA, specializing in neuroimmunology and renal biopsy-derived renal tissue processing. He furthered his research in the fields of immunohistological (immunofluorescence) and electron microscopic examinations during the clinical-morphological correlations in pa- 
tients with renal diseases. He also worked on experimental models of glomerulonephritis. Prof. Polenakovic also held a residency in the United States at the Peter Bent Brigham Hospital, Harvard University in Boston, and the Scripps Clinic La Jolla at San Diego University, California. In 1977 he spent a month in London at the Hammersmith Hospital and at Guy's Hospital, where he became acquainted with modern research on cellular immunity and the treatment of kidney disease patients with immunosuppressive agents. In 1983, as a WHO Fellow, he visited several nephrology university clinics in Stockholm, Munich, and London to learn about new advances in the treatment of renal disease patients with cytostatic agents, cyclosporine, plasmapheresis and the use of immunosuppression in patients with renal transplantation.

Prof. M. Polenakovic participated in the creation of the teaching program of internal propaedeutics and internal medicine for students of medicine and dentistry at the University of Skopje, as well as instructing doctors who were specializing in internal medicine and other specialties. In his postgraduate research at the FM-Skopje, he was the responsible teacher for the modules "clinical foundations of scientific research" and "scientific research methods in nephrology". $\mathrm{He}$ also participated in postgraduate teaching at the University of Nish. For many years, he headed the "Nephrology Tribune" at the Nephrology Clinic for doctors and specialists in the field of nephrology and related disciplines.

Many doctors from SR Macedonia and SFR Yugoslavia were attracted by Prof. Polenakovic's quality of work and teaching and thus came to the Nephrology Clinic for advanced education and training.

As a visiting lecturer he has lectured on endemic nephropathy and glomerulopathies at the nephrology clinics of the Universities of London (1977 and 1983), Turn-Severin, Romania (1978), Leiden, The Netherlands (1979), Dayton (1995), Bologna (1997), Izmir (1999), Aachen (1999), Varna, Thessaloniki (2001), Sofia (2004), Katowice, Zagreb, Dubrovnik, Nish, as well as at the Serbian Academy of Sciences and Arts (SANU) in Belgrade (1982). In the period from 199192, Prof. Polenakovic was a Fulbright Visiting Professor in the United States at the Nephrology Clinic of Northwestern University in Chicago. He has lectured extensively in Chicago, but also in Los Angeles, Houston, Charleston, and at the
National Institutes of Health in Bethesda, Maryland. In 1999-2000 he spent 4 months in Aachen, Germany where he was a mentor for the preparation of numerous master's and doctoral theses.

Prof. M. Polenakovic's professional activity was closely associated with his scientific research and affinities. This all started during his student days and continued into his professional career. He participated in several student congresses with papers in the field of experimental and clinical medicine, two of which were selected and awarded. During his specialization, he mastered clinical approaches in internal medicine and the basics of clinical scientific research, with a special emphasis on nephrology. He then devoted himself to the study of the aetiology and morphology of renal diseases, especially nephroimmunology. Prof. Polenakovic established and managed the Department for etiostructural assessment at the Clinic of Nephrology, along with an outpatient clinic for glomerulopathies and urinary tract infections, a laboratory for renal immunopathology, and an office for ultrasound examination of the kidneys and urinary system. As one of the first nephrologists in SFR Yugoslavia, he introduced renal biopsy and immunohistological examination of renal tissue, but also other modern methods for the examination of the immunity status of patients with renal diseases.

Prof. Polenakovic showed special scientific interest in glomerulonephropathies and their morphological and immunological characteristics, clinical course and prognosis, tubulointerstitial diseases (especially Balkan endemic nephropathy and bacterial interstitial diseases), diabetic nephropathy, polycystic kidney disease, chronic renal failure, dialysis and plasmapheresis. He intensively studied non-invasive methods for the diagnosis of diseases of the urinary system, with a special emphasis on the application of ultrasound technology in nephrology.

The extensive scientific research activity of prof. M. Polenakovic has resulted in the successful implementation of more than 10 scientific research projects in the field of nephrology in Macedonia. These include "Examination of clinical-immune characteristics and course of chronic glomerulonephritis and chronic pyelonephritis" and the project "Nature of haemostatic disorders in patients with renal diseases". He also participated in the scientific project "Protein Metabolic Structures in the As- 
sessment of Immune Conditioned Pathological Conditions of the Kidney and Kidney Failure", as well as collaborated on several international projects, including one on erythropoietin during the 1990 s.

He presented papers at several scientific meetings of nephrologists in the SFRY (Struga, 1977, Dubrovnik 1981, Sarajevo 1987) and at congresses of nephrologists of the SFRY (Belgrade 1979, Zagreb 1983, Ljubljana 1985), as well as in several international congresses of nephrologists (Montreal 1978, Athens 1981, London 1987) and at the Danube Symposia of Nephrologists (Opatija 1984, Baden/Vienna 1985). He has participated in several congresses organized by the European Association for Dialysis and Transplantation (EDTA) and the European Renal Association (ERA), such as in London (1983), Berlin (1987) and others, as well as international congresses for allergology and Clinical Immunology in London (1982), Rome (1983), Opatija (1985), Budapest (1986), Zagreb (1987) and others. Prof. Polenakovic also presented papers at several congresses of doctors of the SR Macedonia, as well as at congresses of pathologists, allergists, and clinical immunologists, paediatricians, haematologists, at the "Balkan Medical Week", and other professional-scientific events.

Prof. Polenakovic actively participated in the organization of the 1st Scientific Meeting of Nephrologists of the SFR Yugoslavia (Struga 1977) and the 1st Congress of Nephrologists of the SFR Yugoslavia (Belgrade 1979), as well as the Symposium on Urinary Tract Infections "Bigorski Scientific Meetings" (Mavrovo 1980), and at the Symposium on Non-Invasive Diagnosis in Nephrology and Renal Osteodystrophy (Ohrid 1987). For several years in a row, starting from 1984, he was the organizer of the professional-scientific event of the Macedonian Medical Society (MMS) and FM-Skopje "Week of news and current events in medicine". He was President of the Organizing Committee for the 4th Congress of Nephrologists of the SFR Yugoslavia (Skopje 1989) and Vice-President of the Organizing Committee of the 18th Congress of the European Association for Dialysis and Transplantation and the European Renal Association (Belgrade 1991). He was the organizer of the 1st Yugoslav-Italian Nephrology Scientific Meeting (Dubrovnik 1988).
Prof. Polenakovic is also the author or co-author of around 500 professional-scientific papers published in both domestic and foreign medical journals, almost half of which are cited in the PubMed database. He has published 7 books and monographs, was the editor of more than 10 collections of proceedings from nephrological scientific gatherings and congresses, wrote several chapters on nephrology in medical textbooks and was the editor of the thematic area "Medicine-Dentistry-Pharmacy-Veterinary" in the main edition of the "Macedonian encyclopaedia", MASA, Skopje, 2009.

Prof. Polenakovic was a member of the Editorial Board of the Macedonian Medical Review (1971-73), as well as of the journals Nephrology, Dialysis, Transplantation (NDT), JAMA (Journal of American Medical Association - Yugoslav Edition), BANTAO Journal, Actual Nephrology (Varna, Bulgaria), and Current Contents in Nephrology (Czech Republic). He was also the Editor-in-Chief of the PubMed-Medline indexed journal of the Macedonian Academy of Sciences and Arts "PRILOZI/Contributions" (2001-2020).

Acad. prof. M. Polenakovic contributed to the development of the Nephrology Clinic by introducing several new methods. He participated in the introduction of the treatment of acute renal failure (ARF) with haemodialysis (HD) in 1965 and chronic renal failure (HRF) with HD in 1971. As a first for Macedonia, he introduced percutaneous renal biopsy and immunochemical methods in the pathomorphological analysis of renal tissue (1970), immunosuppressive therapy and treatment with plasmapheresis of immune diseases, and established a laboratory and Department of Renal Immunology, which he headed from 1975-2005. He participated with a team of experts who performed the first kidney transplant in Macedonia (1977), and introduced subcutaneous erythropoietin treatment to patients with HRF on HD in 1990. He participated in the establishment of several HD centres in Macedonia.

Prof. Polenakovic has also made special contributions to the investigation of glomerular and tubulointerstitial diseases and the Balkan endemic nephropathy, hepatitis in patients with HD, HRF and dialysis and apheresis treatment. He was one of the founders and secretary (1970), 
and later president of the Association of $\mathrm{Ne}$ phrologists at MMS and was one of the founders (1975) and then president (1985-89) of the Association of Nephrologists of the SFR Yugoslavia. Prof. Polenakovic served as president of the Macedonian Association for Basic, Clinical Immunology and Allergology (1992-96).

In a broader sense, Acad. M. Polenakovic had a special interest and initiated research on the history of medicine and, especially, on the history of the FM-Skopje and the first leaders and teachers, both from Macedonia and those who came from other Yugoslav republics. He fulfilled a leadership role in organizing a workshop on April 25th, 2014 for editors of scientific journals on the topic of "Publishing integrity and good practice in editing in biomedicine". Not only this, but he also established the Macedonian Association of Medical Editors (MAME), where he was elected its first president (2014-16), and then honorary president of MAME.

In the period from 1982-90, Prof. Polenakovic performed several managerial and professional-social functions. He was a member of the collegiate governing body of the Clinic of Nephrology, and from 1990-98 was the director of the Nephrology Clinic at the FM-Skopje. He was vice dean of FM-Skopje from 1982-84 and a member of the Council of the University Sts. Cyril and Methodius in Skopje. He was secretary of the Department of Medical Sciences of MASA (2002-2004) and its vice president (2004-2007). Later, he was appointed as the head of the Research Centre for Genetic Engineering and Biotechnology "Gjorgji Efremov" at MASA (2011-17). He was President of the MMS (1984-86), founder and president of the Macedonian Association of Nephrology, Dialysis, Transplantation, and Artificial Organs and one of the founders of the Balkan Association of Nephrology, Dialysis, Transplantation, and Artificial Organs (BANTAO) in 1993. From 1995-97 and 2005-2007, he was President of the aforementioned association. In the period from 1985-89, he was president of the Society of Nephrologists of the Yugoslav Association of Medical Societies. He was a member of the Executive Board of the Agency of Science of the SR Macedonia and President of the Republic Agency for Science in Pharmacy, Health, and Social Care. He was elected as an expert of the Association of Science Agencies in the SFR Yugoslavia and a member of the Commission for Pharmacotherapy and Side Effects, and was also a member of the
Transplant Commission of the Federal Institute for Health Protection in Belgrade.

Acad. Momir Polenakovic remains permanently in the collective memory of our environment as an exceptionally dedicated expert, scientist, and educator - an individual with extraordinary communication and organizational skills, a strategist and a visionary, an organizer and a motivator. Prof. Polenakovic was someone with an acute ability to recognize the values and potential of colleagues and collaborators and was able to assess and successfully delegate, motivate, and coordinate individual and group activities and projects of experts and teams, assembled for professional and scientific research activities.

For his overall professional and professional-social activities, acad. M. Polenakovic received numerous diplomas, certificates of appreciation, as well as professional and social awards. He was awarded a jubilee gold plaque by the FM-Skopje (1987), was awarded the title "Primarius" by the Ministry of Health, the title "Nephrologist" by the Association of Nephrologists of Yugoslavia, and the title "Allergologist and Clinical Immunologist" by the Association of Allergologists and Clinical Immunologists of SFR Yugoslavia. He was elected as an honorary member of the Association of Nephrologists of Bulgaria in 1995. He was additionally chosen as an external member of The Serbian Academy of Sciences and Arts in 1994, and as a member of the Academy of Medical Sciences of the Serbian Medical Association in 1998, and later at the Academy of Medical Sciences of Croatia (2002). He became a full member of the Macedonian Academy of Sciences and Arts on June $26^{\text {th }}, 1997$, a member of the New York Academy of Sciences in 2002, the European Academy of Sciences and Arts in Salzburg in 2006, the World Academy of Arts and Sciences, San Francisco, in 2006 and the Leibnitz Scientific Society in Berlin in 2007.

He was awarded the Yugoslavian Order of Labour with a silver wreath. The Macedonian Medical Society awarded him with a Certificate of Appreciation, a Plaque and the Charter "Dr. Trifun Panovski" (1988). He has been presented with several international awards, including honorary plaques for the establishment of BANTAO, in Thessaloniki (2001) and Varna (2003), and The Distinguished International Medal from the National Kidney Foundation in the United States (1997). 
The Clinic for Nephrology, FM-Skopje, and the University of Skopje, as well as the members and the management of MASA will be forever grateful for Prof. Polenakovic's dedication and contribution to the development and achievements in health, teaching, and scientific work, but also for his contribution to the overall activity and success of MASA. Also, the younger generations of students, doctors, and lecturers, to whom Prof. M. Polenakovic was a teacher and, of course, his patients, to whom he was selflessly committed to helping even after retirement, shall be forever grateful for his work and achievements.

May he rest in peace and may his glory be eternal! 